Универзитет у Новом Саду, Филозофски фракултет Одсек за историју, Нови Сад

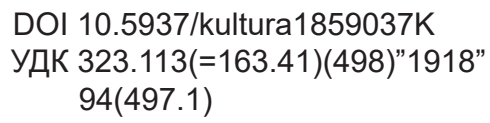

прегледни рад

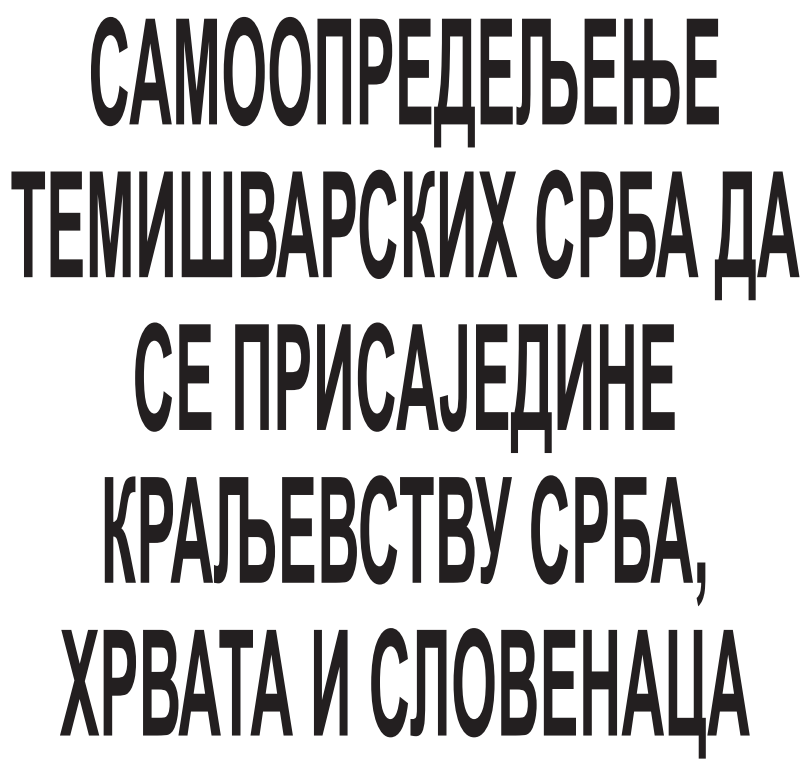

Сажетак: Пред крај Првог светског рата на територијама Аустро-угарске монархије на којима су живели Срби настају народна већа као чин самоопредељења. Међутим, не може се рећи да су Срби у Темишвару били национално свесни иако су преко српског темишварског Народног већа показали жељу да се присаједине својој браћи. Услед година мађаризаџије и германизаџије међу собом су причали туђим језиком. Утицајни Темишварци, национални радници, чланови већа, радили су на томе да се такво стање измени. Одговоривщи на позив српског Народног одбора у Новом Саду послали су изасланике за Велику Народну скупштину у Нови Сад. Скупштина одржана 25. новембра 1918. године представљаће изузетан историјски чин када ће се Банат, Бачка и Барања присајединити првој југословенској држави. Темишвар ће се у склопу Баната припојити новој држави као територија коју су српска и савезничка војска заузеле а чије је српско становништво изразило жељу за тим. Међутим, Конференција мира у Паризу доделиће Темишвар Краљевини Румунији.

Кључне речи: Темишвар, новембар 1918. године, Велика Народна скупштина у Новом Саду, српско темишварско Народно веће, самоопредељење, присаједињење Краљевини СХС 


\section{JOBAНА КАСАШ}

Ми се од стабла свога оиепити не можемо, рећи ће Младен Пилић, потпредседник оформљеног српског темишварског Народног већа, на великом збору Срба Темишвараца грађана и војника 31. (18.) октобра 1918. године. ${ }^{1}$ Пилић ће даље истаћи да је потребно установити које су жеље Срба и којим путем би их они могли остварити, поред тога што ће у Темишвару учествовати у раду заједничког Банатског народног већа, које је раније тога дана настало када је проглашена и Банатска република. „Тежње су наше народна самосталност српскога народа у вези и договору са целим народом, који је под именом Југословена обухваћен", обнародоваће Пилић. ${ }^{2}$ На такве жеље Младена Пилића да се српска идеја оствари у југословенској држави присутни Темишварци реаговали су бурним поклицима одобравања а српско темишварско Народно веће тиме је показало да је његова крајња тежња била припајање будућој Краљевини Срба, Хрвата и Словенаца, иако признаје оснивање Банатске републике. Српски лист, орган српског Народног одбора у Новом Саду у свом другом броју писао је да су „банатске Швабе” образовале „своје Народно веће” а да се Срби у Банату „нису одвојили од своје остале браће” и да неће пристати на ту „нову државу”. ${ }^{3}$ Крај октобра и почетак новембра 1918. године тако постаје време када на територији бивше Аустроугарске, где су живели Срби, настају народна већа као чин самоопредељења а српско Народно веће у Темишвару један од првих ако не и први, српски орган народне власти у бившој Угарској. Међутим, не може се рећи да су Срби у Темишвару били национално свесни, иако су показивали жељу да се присаједине својој браћи. Услед година мађаризације и германизације, међу собом су причали најчешће мађарским језиком, нису носили српска обележја, ни славили крсну славу а у Темишвару није излазио ни један лист на српском језику. Срби у већу, утицајни Темишварци, национални радници, радили су на томе да се такво стање измени и да преко већа припреме присаједињење са Краљевином Србијом.

Крај Првог светског рата Срби у темишварском Банату дочекаће схватања да Аустро-угарска монархија због „националне неравноправности није њихова права домовина". ${ }^{4}$ Њихов отпор према рату показаће жељу за променом владајућег

1 Приредио: Храбак, Б. (1955) Записник темишварског Народног већа, Зборник Матице српске - серија друштвених наука, бр. 10, Нови Сад, Научно одељење Матице српске, стр. 77.

2 Исто.

3 Аноним (24. октобар 1918) Српски лист, бр. 2, Нови Сад, стр. 4.

4 Hrabak, B. (1979) Logoši, zeleni kadar i zbivanja pri prevratu u Vojvodini 1918, Istraživanja, br. 8, Novi Sad, Institut za istoriju Novi Sad, str. 113. 


\section{JOBAНА КАСАШ}

режима и чежњу за националним уједињењем са слободним државама изван „Црно-жуте” Монархије. ${ }^{5}$ Темишвар је у то време био центар Баната али Темишвар није био српска варош. У граду од 70 хиљада становника живело је четири и по хиљаде Срба. О таквом Темишвару сазнајемо из писања великог Милоша Црњанског који је у њему живео до 1912. године. Сећања Црњанског представљају значајне изворе о животу, навикама али и о проблемима темишварских Срба пре почетка Првог светског рата. Како је писао Црњански, Темишвар је у тим годинама био „модерна и раскошна варош, са широким авенијама и парковима” и „свет се ту шетао, као што се у Италији шета”. Називали су га „Малим Бечом"7.У Темишвару, у порти српске Саборне цркве, преко пута католичке катедрале, налазила се мала школа српског учитеља Душана Берића код кога је Црњански учио четири основна разреда. Да је био уложен велики труд да српска деца од малена буду упозната о народним и црквеним правима Срба у Аустроугарској видимо на основу сведочења Црњанског, који за свог учитеља каже како је он био експерт за ова питања и да је њих, ученике, свако вече окупљао код себе да им о томе прича. ${ }^{8}$ У свом делу О Банату и о Банаћанимa, Милош Црњански такође пише како је Темишвар нагло растао и развијао се, да се налазио на води и имао веслачке клубове а да су се жене у тој вароши облачиле по последњој моди из Париза, увезеној преко Беча. ${ }^{9}$ Млади писац је до матуре живео са мајком, као што су у то време живела сва „варошка деца”. ${ }^{10}$ Дружио се са децом католика, племића и како каже са њиховим „намирисаним сестрама” са којима је похађао часове француског. ${ }^{11}$ Упоредо је похађао и часове енглеског језика и сликарства али то није био израз „никаквог снобизма” него једна „уобичајена појава” у Темишвару тога времена. ${ }^{12}$ Ипак, Црњански је живео и међу радницима. У клубу железничара, металаца играо је фудбал, где му је најбољи друг био металац Сидон па је тако у његовом друштву, како пише, упознао језик, кућу и породични живот радника али и литературу социјализма. ${ }^{13}$

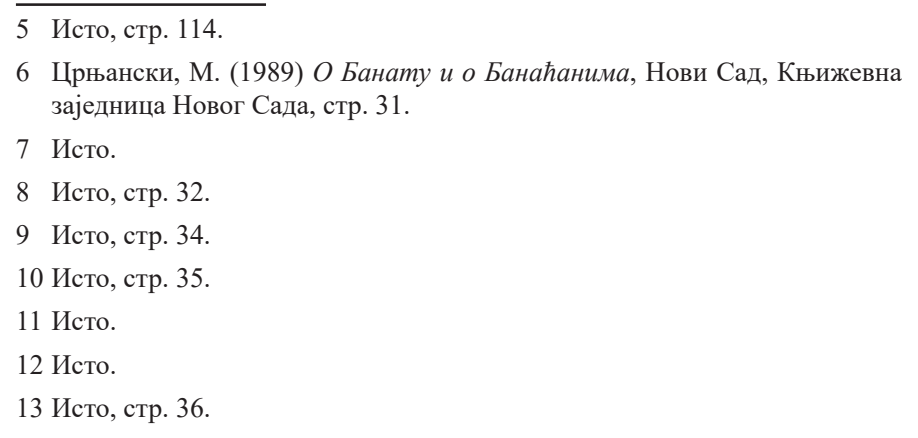


За нашу тему последњи пасуси из сећања Милоша Црњанског су уједно и најважнији. Његова сведочења су важна да би се разумео положај Срба у Темишвару и да би се разумело зашто су они природно нагињали да се уједине у прву југословенску државу. Црњански каже, да је поред тог Темишвара, Темишвара мађарских племића и Темишвара пролетера и металаца, постајао и један други Темишвар, којем је тада припадала и „породица Црњански и душом и телом”. ${ }^{14}$ То је био Темишвар Срба. „Варош стара, умирућа, фанатична, верска. Дијаспора, као и Темишвар Јевреја”, писао је Црњански. ${ }^{15}$ Такав Темишвар је „срастао са Темишварем туђина, као два сијамска близанца, али окренута леђима”. ${ }^{6}$ „У том Темишвару бранила се свака српска кућа, као барикада”, истиче Црњански а нама представља податак од суштинске важности из тог времена. ${ }^{17}$ Црњански том приликом описује и како су Срби у Темишвару прослављали хришћански празник Духове а потом и Ускрс. На Духове се у цркве уноси свежа зелена трава и цвеће а после свете литургије служи се вечерње, на којем се клечи и плету се венци од цвећа. Црњански пише да су и темишварски Срби то радили а да су те венце стављали изнад својих врата „као неки знак завереника“. ${ }^{18}$ Уочи Ускрса, на Велики петак, сећа се Милош Црњански „на сред цркве имали смо гроб Христа, у цвећу, а чувала га је стража војника домаће регименте Темишвара, двадесет и девете, састављене у $80 \%$ од Срба. За време најсвечанијег тренутка службе у цркву би упао наредник, са два војника, под клобуком, у цокулама, да смени стражу. Ударили би о патос ђоновима. Ствар је била глупава, али се Темишварцима чинила торжествена. О поноћи, кад би литија обилазила, пред црквом је био постројен батаљон да парада буде што већа. Ја сам у том Темишвару писао песме”, завршава Милош Црњански. ${ }^{19}$

Када се темишварско српско Народно веће оформило на великом народном сабору Срба у Темишвару 31. октобра 1918. године било је свесно да свака српска кућа мора да се брани као барикада, како је пар година раније писао Милош Црњански. У циљу јачања националне свести код Срба у Темишвару на својим седницама донеће низ одлука у том правцу. Једна од њих била је да је „сваки Србин дужан носити српску тробојницу, као видно обележје своје народне

14 Црњански, М. нав. дело, стр. 37.

15 Исто.

16 Исто.

17 Исто.

18 Исто.

19 Исто, стр. 38-39. 


\section{JOBAНА КАСАШ}

припадности” и да „благајник већа да̂ да се од српске тробојнице начине кокарде", а они који су одређени да скупљају прилоге да се помогне рад већа требало је да их поделе. ${ }^{20}$

Велики проблем који је успоравао културни развој Срба у Темишвару био је тај што у Темишвару ни један лист није излазио на српском језику. Да би становништво Темишвара било обавештено о раду Народног већа на седницама је закључено и да се издају званични извештаји. Из истог разлога а и због агитационе политике, на седници већа, 3. новембра (21. октобра) 1918. године, решено је да се у Темишвару покрене један српски лист. ${ }^{21}$ Биће то Слога, информативно-политички лист, који ће почети да излази 11. децембра (28. новембра) 1918. године. Овакав лист требао је „да уђе у сваку српску кућу” као и да изнесе „праву истину и поуку". 22 За уредника листа биће изабран Илија Белеслијин, члан српског Народног већа. ${ }^{23}$ Лист Слога постаће тако веома важно политичко и културно средство темишварских Срба. Лист ће бити покренут уз подршку српске војске која је у град ушла 17. новембра 1918. године. Генерал Ђорђевић, који ће се налазити у Темишвару, сматраће да лист, који би излазио у овом граду, треба да пише у духу какав он предлаже. Када је писао својим претпостављенима истицао је да ће га контролисати, а уколико буде скренуо са тог правца, лист ће забранити. ${ }^{24}$ Тако ће се после више од две деценије на територији данашње Румуније појавити лист на српском језику. ${ }^{25}$ На страницама Слоге изражаваће се сва драматика овог историјског раскршћа јер ће се у времену његовог излажења водити дипломатска битка да Темишварски Банат остане у границама Краљевине Срба, Хрвата и Словенаца.

Проблем је био и тај што и после слома Аустроугарске у Темишвару ни Срби нису међу собом говорили српским језиком. Управо ће уредништво листа Слога донети чланак под насловом Говори српски!, у којем ће нагласити да се ова

20 Записник са седнице 7. новембар (25. октобар) 1918. године; приредио: Храбак, Б. (1955) Записник темишварског Народног већа, Зборник Матице српске - серија друштвених наука, бр. 10, Нови Сад, Научно одељење Матице српске, стр. 85.

21 Попов, Д. (1983) Српска штампа у Војводини 1918-1941, Нови Сад, Матица српска, стр. 62.

22 Исто.

23 Приредио: Храбак, Б. (1955) Записник темишварског Народног већа, Зборник Матице српске - серија друштвених наука, бр. 10, Нови Сад, Научно одељење Матице српске, стр. 85.

24 Војни Архив, П. 3.

25 Бугарски, С. (2014) Српска периодика на тлу данашње Румуније, Нови Сад, Друштво новинара Војводине: Мало историјско друштво, стр. 515. 
опомена односи највише на Темишвар и његову околину ,jер ако се и где мало говори српски" у Темишвару се говори „необично мало”. ${ }^{26}$ Уредништво се жалило на оне којима је српски језик матерњи, а служе се страним језиком и то не само у „додиру са туђим народностима, већ и у опхођењу са својим рођенима” и не само „у јавним државним звањима, како су то научили под крутом мађарском деспотијом, већ и у приватном и породичном животу?!"27 Пре него што је у град ушла српска војска, како пише Слога, Срби су изгледали као да су се порумунили, понемчили и помађарили. ${ }^{28}$ „Кудгод се човек макне, кога ли год сретне... чује се само туђ разговор мађарски, немачки и румунски... Чује ли међутим српску реч, чисто се тргне и помисли, да је пала бела врана с неба...Преко свега пак, најжалосније је још то, што ни по приватним кућама није боље. По такозваним угледнијим кућама преовлађује више немачки и мађарски говор. По осталим румунски. И кад је човек свестан тога треба да довикне: Говори српски! Та српски говор треба да је свакоме Србину идеал...Он му је дар од Бога....Без тога свога говора, ниси брате мој Србин. Ниси ни брат данашњих хероја, који ти слободу донеше", писало је уредништво мислећи недвосмислено на српску краљевску војску. ${ }^{29}$ Незадовољно оваквим стањем, уредништво признаје да у Темишвару ситуација није много боља ни после доласка српске војске, а једино што се променило је то што Срби Темишварци сада могу да слушају војнике како српски говоре. Темишвару граду су у то време била придодата његова предграђа Фабрика и Мехала, па је Слога писала у наставку чланка да када би неко ушао у цркву, било градску, било фабричку било мехалску, не би чуо српски језик. У фабричкој цркви је преовладавао немачки и мађарски говор, а у мехалској румунски. „Чисто човек помисли, пре да је у каквим црквама, него у православној”, писала је темишварска Слога. Српска омладина у Темишвару је такође причала страним језиком, што је посебно бринуло утицајне Темишварце. ${ }^{30}$ Српској омладини темишварској указивало се на то реченицама: „Ми знамо целу светску историју, само свога народа не. Ми познајемо Гетеа, Ибзена и Толстоја, читамо Шилера, гледамо Ростена, Мољера и Шекспира, али о својим песницима, о Вуку Караџићу, о Бранку Радичевићу, о Змај-Јовану појма немамо.”з1

26 Аноним, (1. мај 1919) Говори српски, Слога, бр. 116, Темишвар, стр. 1.

27 Исто.

28 Исто.

29 Исто.

30 Исто.

31 Аноним, (11. децембар 1918) Слога, бр. 12, Темишвар, стр. 1. 


\section{JOBAНА КАСАШ}

Из тих разлога наметало се мишљење да је потребно основати једно омладинско удружење. „То удружење би позвано било, да нас светлости приведе, да се у крилу његовоме скупљамо и помоћу декламовања, песама, предавања читања и т. д. колико толико усавршимо. Позвано би било, да из душа наших и срдаца наших искорени страни дух и да нас привикава на победоносну демокрацију и тиме спрема за живот... Мало нас Срба има, и то се не познаје, не зна једно за друго и тако се изгубисмо у огромној већини других народности. Сада када су нам руке одрешене, сада оно можемо говорити и радити, шта хоћемо, где хоћемо, сада треба да уграбимо прилику без оклевања, без премишљања лепо и одважно“, поручивала је Слога. ${ }^{32}$

Коло Младих Срба, које је тада основано у Темишвару, постало је важан културни чинилац захваљујући поселима и драмским програмима које је организовало. Оно је неговало националну културу и будило српска осећања код грађана, посебно омладине. Вредне помена биле су и гимназијске беседе, студентске приредбе и културни програми Српске добротворне женске задруге. ${ }^{33}$ Председник Кола Младих Срба био је др Јован Савковић, члан српског темишварског Народног већа. Вест о оснивању оваквог друштва лист Слога донео је речима: „После робовања, после тешких учмалости, наступило је доба рада, доба живота. И наша темишварска омладина, видевши се ослобођеном, отпочиње живот...” Одлучено је да се приређују села, која би имала поучно-забавни карактер. На њима ће се као говорници ређати угледни Темишварци, попут председника Кола, Јована Савковића, али и српског генерала Панте Грујића, команданта банатских трупа. Велику част овом темишварском друштву указао је епископ темишварски др Георгије Летић. Тада су селу присуствовали и људи из околине Темишвара, тако да је сала Касине била пуна. На десетом селу омладинцима се придружио са својим прецизним и јасним предавањима, и Стеван Бенин, шеф Пресбироа у Темишвару. Слога је писала да су „добра воља, жеља да припомогну око прикупљања Српства и труд” људи који су учествовали у раду Кола Младих Срба, „достојни највеће хвале” а „колико је пак рад омладине наше утицао на околину види се и по томе, што је много места зову, да и тамо прикаже извесне делове својих досадашњих програма”. Слога је такође писала и да „овим позивима ће се Коло свакако одазвати, а Темишвару збиља служи на част што има такве своје синове, који знају да чувају и бране српску реч. Исти Темишвар је од увек

\section{2 Исто.}

33 Церовић, Љ. (1997) Срби у Румунији, Нови Сад, Матица српска, стр. 365. 
био центар Баната, па он ће то и у будуће бити. Биће зато што будући наши нараштаји траже да се у овом старом српском месту увек чује српска песма, српска реч. Коло Младих Срба је до сада на томе радило и у будуће ће радити. Оно је управо претеча свију других културних покрета, који ће се овде у Темишвару за Банат одигравати. А ми ћемо га сви и даље помагати да врши свој благотворни утицај”, писала је Слога. ${ }^{34}$ Илија Белеслијин, већ поменути члан српског Народног већа, на прослави прве Нове године у ослобођеном Темишвару 1919. године рећи ће: „До сад смо имали Обилиће на бојном пољу, од сада ћемо их гледати на културном"35 и заиста је било тако.

Веома је било важно и да се отпочне просветни рад. „У српским крајевима, које је српска војска запосела осећа се живље кретање српства. То исто покушавају и Срби на мртвој стражи, - који до сада које што нису смели а које у мору туђинства што се изгубили - врло ретко се јављали. Сад би требало свом снагом то учмало Српство пробудити. Основати му певачку дружину, соколска друштва, читаоницу, задругу, земљорадничко, антиалкохолно друштво (по примеру тих друштава у Србији) женске задруге, које би одмах на се узеле и бригу за многу сироту и незаштићену децу. Ту би могли на поучним селима обавестити се о свему што је Србину сад потребно да посвршава - а уједно у српским осећајима, у братској југословенској слози учврстимо. Из историје дознали би сву нашу славну прошлост, као и наше жалосне дане и узроке у тим жалосним данима. Нека омладина, просветни радници, свештеници, учитељи, бележници, трговци уједињени сад све створе - јер им сад не може на пут стати мађарски шовинизам са угњетавањем не дајући им просторије или пак саму дозволу. То српске власти неће чинити. Отпочните дакле просветни рад!”, упозоравао је такође лист Слога. ${ }^{36}$

У циљу обнављања српских обичаја у новој држави, слављења крсне славе међу Србима у Темишвару, Слога је такође донела неколико речи. „Сада су Срби слободни и нема никаквих сметњи да славе своју крсну славу...Захваљујући српској војсци, која је одржавала обичаје да се одржи наше име, дика и слава, обележја нашег јуначког и племенитог народа” и „под кишом олова у непосредној близини непријатеља, међу урвинама и стенама”. ${ }^{37}$ „Ко крсно име слави томе и

34 Аноним, (16. април 1919) Слога, бр. 104. Темишвар, стр. 1.

35 Аноним (2. јануар 1919) Слога, бр. 27, Темишвар, стр. 2.

36 Аноним, (1. фебруар 1919) Слога, бр. 42, Темишвар, стр. 1.

37 Аноним, (11. децембар 1918) Слога, бр.12, Темишвар, стр. 1. 


\section{JOBAНА КАСАШ}

Бог помаже”. Даље поменути лист пише о корену слављења славе код Срба. Када су као словенско племе били пагани, свака породица је бирала идола, а када је народ примио хришћанство, задржао је тај свој стари обичај али у другој форми, односно примио је крсно име. Крштења су се обично дешавала током већих празника, а породице би тај дан, када су прешле у хришћанство, узимале као дан славе. Српска слава се задржала и до времена после Првог светског рата свуда где је било српског народа и није се могла избрисати из обичаја „ни током највећих народњих патњи, ни столетним робовањем". Готово све јавне установе, храмови и друштва славе један дан у години као своје крсно име. „Тако слави своју славу и свака јединица наше дичне и храбре српске војске”. Наши пукови од првога дана славе српску славу, а слављени светитељ је услишио њихове молитве и помогао им у борби да достојно испуне и одрже положену заклетву спрам краља и отаџбине. Обичај слављења се одржао код наше браће на Балкану много боље но код нас у Банату, а нарочито у Пијемонту наших националних идеја - Краљевини Србији. Тамо прослављају крсно име, почевши од поглавара земље Њ. В. Краља, сви, па и најсиромашнији члан српског живља. Крсну славу Светог Николу у Темишвару је прославио и генерал Ђорђе Ђорђевић, командант трупа савезног Баната и пуковник Цоловић, командант I коњичке бригаде и многи други виши и нижи официри и војници. „Заиста су величанствени ови моменти за нас, када видимо рођеним очима, где се у главној вароши нашег питомог Баната, а где се још до скора робовало, обављају лепи српски обичаји. Нехотице нас прођу жмарци утицајем здравица, отпоздрава: лепога српског гостопримства и свега онога, што при овим свечаним моментима инстиктивно произлазе из чисте српске душе, која слави без лицемерства, из правих и дубоких, искрених осећаја. Ми се осећамо сретни, пресретни што видимо, што смо сведоци, да се стара српска слава одржала у бурној успомени код нашег живља овде у Темишвару понова покренемо живо интересовање за све наше обичаје, који су се у последње време почели губити а црпићемо примере од наше браће, који су нас ослободили, да и у нас улију, оживе поново праву српску крв, оригинални карактер нашега народа уопште. Године 1919. 18. јануара на дан св. Атанасиje, имаћемо прилике, да будемо саучесници славе I пешадијског пука, који је примио дан ослобођења Врање 1878. год. за дан пуковског крсног имена, које се сваке године достојно прославља, на дику и част српског победоносног оружја”, поручивала је Слога.

Поред обнављања културног живота у Темишвару и јачања националне припадности код Срба, српско Народно веће 


\section{JOBAНА КАСАШ}

имало је још један, а можда и најважнији задатак, а то је припремање уједињења са Краљевином Србијом, односно са Краљевством Словенаца, Хрвата и Срба. На већ поменутој првој седници темишварског српског Народног већа 31. (18) октобра 1918. године оформљен је један припремни одбор у који су једногласно изабрани Младен Пилић, др Јован Савковић, др Душан Прекајски, Јоца Павловић и Ђура Терзин с тим да се одбор по потреби прошири. ${ }^{38}$ Том приликом поведена је и дискусија о незаступљености српског свештенства у овом одбору, на шта је посебно негодовао Илија Белеслијин. Пилић је тада изјавио да је више свештеника питано да уђу у одбор, али су они то одбили. Будући да Илија Белеслијин „изражава готовост своју да народну ствар од своје стране потпомогне", збор темишварских Срба га једногласно бира у припремни одбор заједно са адвокатом др Миланом Калиновићем. ${ }^{39}$ Овакав одбор требало је да спроведе само организацију и да буде кратког века јер би требало да га убрзо замени један шири одбор изабран од целога народа, велики народни Савет Срба у Угарској, чиме се свакако мисли на будућу Велику народну скупштинну у Новом Саду. „У ту сврху треба нам потражити додира са свима Србима у Угарској”, расправљало се даље на седницама темишварског већа. У наредним данима, одговоривши на позив Народног одбора у Новом Саду и Темишвар ће послати своје представнике за Велику Народну скупштину у Новом Саду. Из изборног записника вођеног у Темишвару 22. (9.) новембра 1918. године на збору Срба Темишвараца тога дана, уз констатовање чињеница, „да у Темишвару број Срба добрим премаша број 4.500"40, једногласно је за подручје Града, Фабрике и Мехале изабрано пет посланика. У Рукописном одељењу Матице српске чувају се Веродајнице које је српско Народно веће у Темишвару издало Илији Белеслијину, пароху у темишварском предграђу Фабрици и потпредседнику српског Народног већа, као изасланику на Великој народној скупштини. Такође, и Ђури Терзину, српском народном учитељу у Темишвару, секретару српског Народног већа темишварског, као и др Васи Богданову, адвокату, члану извршног одбора српског Народног већа темишварског. Веродајнице Христифора Свирчевића и Слободана Костића нису сачуване, али њихова имена су на изборном списку у документу са седнице збора. Овај документ такође

38 Приредио: Храбак, Б. (1955) Записник темишварског Народног већа, Зборник Матице српске - серија друштвених наука, бр. 10, Нови Сад, Научно одељење Матице српске, стр. 77-78.

39 Исто, стр. 8.

40 Рукописно одељење Матице српске Велика народна скупштина Војводине 1918. Пуномоћи посланика М. 7.417. 


\section{JOBAНА КАСАШ}

се чува у Рукописном одељењу Матице српске у фонду Пуномоћи посланика. ${ }^{41}$ Срби Темишварци преко ових посланика директно су учествовали у раду Велике Народне скупштине у Новом Саду. ${ }^{42}$ Велика Народна скупштина, која је одржана 25. новембра 1918. године, представљаће изузетан историјски чин када ће се Банат, Бачка и Барања присајединити будућој држави Срба, Хрвата и Словенаца. Темишвар ће се у склопу Баната такође припојити новој држави као територија коју је српска војска заузела а чије је српско становништво изразило жељу за тим. ${ }^{43}$

Годину дана касније након овог историјског догађаја, уредништво Слоге већ је било пресељено у Велики Бечкерек услед евакуације Темишвара. Односно, када се славила годишњица одржавања Велике Народне скупштине, одлуке донете на скупштини, у случају Темишвара нису биле испоштоване. Лист Слога је ипак обележио ову годишњицу и писао: „Данас слави Српство из БББ годишњицу онога сјајнога дана, када је на величанственој Народној Скупштини у Новом Саду изречена потпуна оцепљеност од Мађарске и сједињење са мајком Србијом. Како је то лепо било! Из очију свију учесника читао си радост, занос и благодарност према онима који су му слободу и уједињење донели". ${ }^{4}$ Илија Белеслијин, представник града Темишвара на Великој Народној скупштини у Новом Саду, изјавиће на банкету поводом прославе десетогодишњице присаједињења Војводине Краљевини Србији да је он сам учествовао у стварању Краљевине. Белеслијин се сећао: „Ту је речима оцртана једна отаџбина, за којом је чезнула наша душа. То је била једна отаџбина у којој нема мањина ни већина, нема повлашћених ни подвлашћених, нема грађана правих и неправих. Једнакост и братство у правима и у дужностима, то је био идеал нашега дичнога тића Светозара Милетића и наш. Требало је да се оствари, што се тако неистинито говорило, да нема живота као што је живот у Угарској, а и ако га има, он није такав. Тај идеал остао је само идеал али остварен није био

41 Рукописно одељење Матице српске Велика народна скупштина Војводине 1918. Пуномоћи посланика М. 7.417.

42 Његован, Д. (1993) Присаједињење Срема, Баната, Бачке и Барање Србији 1918, Нови Сад, стр. 91; Pekić, Р. (1939) Povijest oslobođenja Vojvodine, Subotica, Grafika, str. 309

43 Дана 1. децембра 1918. године лист Слога пренела је честитку српског Народног већа у Темишвару Његовом Височанству Александру регенту државе Срба, Хрвата и Словенаца уз речи „да се поуздано нада да ће мудрости Височанства и повећаној Србији успети да се спасоносна власт Нове Краљевине што пре протегне и на мезимче њезино, на Банат, Бачку и Барању"; Аноним (1. децембар 1918) Слога, бр. 4, Темишвар, стр. 1.

44 Аноним, (25. новембар 1919) Слога, бр. 266. Велики Бечкерек, стр. 2. 
никада...Такав је устав лебдио и нама пред очима, изражен у бечкеречком програму. И такву смо отаџбину тражили, кад је код куће нисмо нашли. И нашли смо је у државној творени краља Петра. Ту смо нашли остварен идеал отаџбине, коју је велики краљ изградио за двадесет година. И ми смо бацали чежњиве погледе у ту дивну отаџбину, јер је у њој остварен дух времена, који је био таки, да за слободу гине сваки. Отаџбину не моју, него нашу, где међу грађанима није било преграда, ни вере, ни језика, ни боје коже, ни расе. И када је ту чежњу видео велики краљ, он је тргао мач из корица и испретурао престоле краљевске и царске мучном борбом од осам година. И тој грозним ратним недаћама разореној земљи предали смо ми пре десет година нашу дивну Војводину на вечна времена. ${ }^{45}$

Др Милорад Недељковић је на банкету у част српске војске наздравио Војвођанима, који су „ослобођењем уведени у ред највећега племства, у ред слободних српских грађана”. Том приликом рекао је да су „чудна Божија дела јер ко би се још могао пре неколико недеља надати да ће Срби у Темишвару бити овако пресретни и да ће у слободном Темишвару присаједињеним Краљевини Србији, седети у друштву српских војника и славити њихове победе”. Изјавио је и да су Срби пре неколико недеља били „бескућници без отаџбине и робови”, а сада се, победом српске војске у рату, све изменило. ${ }^{46}$ Улазак савезничке и српске војске у Банат заиста је битно променио статус Срба у Темишвару. Од прогоњених, интернираних, а у последњој години рата невољно толерисаних они су сада постали пуноправни грађани једне нове државе. Међутим, Мировна конференција у Паризу донеће одлуку да се Банат подели између Румуније, Мађарске и Краљевине Срба, Хрвата и Словенаца и да се овај град, центар Баната и некадашњи главни град Српске Војводине и Срби који су у њему живели, предају Краљевини Румунији по етничком принципу разграничења. ${ }^{47}$ Већину у Темишвару у то време чинили су Немци и Мађари, који као ни српско ни румунско становништво нису питани коме желе да припадну путем плебисцита. Жељама темишварских Срба да се нађу у заједничкој држави са својом браћом није удовољено. Српска војска евакуисаће Темишвар са околином 28. јула 1919. године. Разграничење између Краљевине Срба, Хрвата и Словенаца и Краљевине Румуније после Првог светског рата ће на тај начин трајно одредити

45 Рукописно одељење Матице српске М. 12. 512.

46 Савковић, J. (19. децембар 1918) Слога, бр. 18, Темишвар, стр. 1.

47 Mitrović, A. (1975) Razgraničenje Jugoslavije sa Mađarskom i Rumunijom 1919-1920, Novi Sad, Institut za izučavanje istorije Vojvodine, str. 261. 


\section{JOBAНА КАСАШ}

историјску судбину Срба Темишвараца. Срби који ће остати у Темишвару прилагођаваће се новом положају националне мањине. Велики број Срба, међутим, напустиће Темишвар јер неће желети да живи у Румунији. Коментаришући сеобу Срба који нису хтели да остану у туђој држави него да се ипак нађу у Краљевини Срба, Хрвата и Словенаца, Мирко Терзић, српски национални делатник, писаће: „Нама Србима је - још од Чарнојевића - селидба као неки шпорт. И то је најбоље." 48

\section{Извори:}

Војни Архив, Београд

Рукописно одељење Матице српске, Нови Сад

\section{ЛИТЕРАТУРА:}

Бугарски, С. (2014) Српска периодика на тлу данашње Румуније, Нови Сад, Друштво новинара Војводине: Мало историјско друштво.

Касаш, J. (2018) Улазак српске краљевске војске у Темишвар 17. новембра 1918. године, Attendite: Гласник Историјског архива у Кикинди, бр. 14, Кикинда, стр. 177-190.

Mitrović, A. (1975) Razgraničenje Jugoslavije sa Mađarskom i Rumunijom 1919-1920, Novi Sad, Institut za izučavanje istorije Vojvodine.

Његован, Д. (1993) Присаједињење Срема, Баната, Бачке и Барање Србији 1918, Нови Сад: Музеј Војводине.

Pekić, P. (1939) Povijest oslobođenja Vojvodine, Subotica, Grafika.

Попов, Д. (1983) Српска штампа у Војводини 1918-1941, Нови Сад, Матица српска.

Храбак, Б. (1955) Записник темишварског Народног већа, Зборник Матице српске - серија друштвених наука, бр. 10, Нови Сад, Научно одељење Матице српске, стр. 76-88.

Hrabak, B. (1979) Logoši, zeleni kadar i zbivanja pri prevratu u Vojvodini 1918, Istraživanja, br. 8, Novi Sad, Institut za istoriju Novi Sad, str. 113-137.

Церовић, Љ. (1997) Срби у Румунији, Нови Сад, Матица српска.

Црњански, М. (1989) О Банату и о Банаћанима, Нови Сад: Књижевна заједница Новог Сада.

Слога $(1918,1919)$

Српски лист (1918)

48 Терзић, М. (25. септембар 1919) Слога, бр. 222. Велики Бечкерек, стр. 1. 
JOBAНА КАСАШ

Jovana Kasaš

University in Novi Sad, Faculty of Philology History Department, Novi Sad

\title{
SELF-DETERMINATION OF THE TIMISOARA SERBS TO JOIN THE KINGDOM OF SERBS, CROATS AND SLOVENIANS
}

\begin{abstract}
At the end of the First World War, as an act of self-determination, national councils were set up on the territory of the Austro-Hungarian Empire, in the parts inhabited by Serbs. It cannot be said in all certainty that the Serbs from Timisoara were nationally conscious, although they did express their wish to join their compatriots. Due to the longstanding Hungarization and Germanization, they mostly communicated in Hungarian, they did not carry Serbian emblems, and there were not any newspapers written in Serbian in Timisoara. The Serbs present in the Council, influential citizens of Timisoara and national activists took pains to change such state of affairs. In response to the call from the People's Board in Novi Sad, Timisoara also sent their representatives to the Great Peoples' Assembly in Novi Sad. The session of the Great Peoples' Assembly held on November 25, 1918 was to represent an exceptional historical act by which the regions of Banat, Bačka and Baranja were to unite with the future State of the Serbs, Croats and Slovenians. Timisoara, as part of the Banat region, was also to join the new state as the territory conquered by the Serbian army, where the Serbian population expressed the wish for it. However, the Peace Conference in Paris was to give this city, along with the Serbs who lived in it, over to the Kingdom of Romania.
\end{abstract}

Key words: Timisoara, November 1918, the Great People's Assembly in Novi Sad, the Serbian People's Council in Timisoara, selfdetermination, unification with the Kingdom of Serbs, Croats and Slovenians 